New Jersey History 125:2

\title{
"When the Cat is Away the Mice Will Work": Thomas Alva Edison and the Insomnia Squad
}

\author{
Thomas E. Jeffrey ${ }^{1}$
}

\begin{abstract}
Over the past one hundred years, the phrase "Insomnia Squad" has evolved from an inside joke among a few of Thomas Edison's laboratory staffers into a term of popular culture, familiar even to school children. Yet very little has been written about the seven experimenters who constituted the task force that Edison assembled in September 1912, why the inventor chose these particular individuals to assist him, the nature of the problem with which he was grappling, or how it was ultimately resolved. Edison and his assistants worked night and day for five weeks with only a minimal amount of sleep, yet no adequate explanation has been offered as to why the inventor drove his men so hard. This article, based on the documents in the microfilm and digital editions of the Thomas A. Edison Papers, reveals that this period of intense activity coincided with a family crisis, as Edison's wife Mina rushed to Akron, Ohio, to tend to her dying mother, while her inventor husband raced to perfect the Diamond Disc record before he was called away to attend the funeral. With a million dollars worth of phonographs piled up in the warehouse and no records to sell along with them, Edison and his men pushed round the clock to work out the bugs in the manufacturing process and bring the Diamond Disc to market. Although seven experimenters assisted Edison, only six appear in the group photograph that was taken at the end of the marathon session. The identity of the seventh "Insomniac" is revealed at the end of the article.
\end{abstract}

One of the keys to Edison's success as an inventor was his willingness to work long hours for extended periods of time. It has been accurately observed that Edison's life "was the kind of 24-7 existence that the dot-commers claimed to have invented. Edison lived on Internet time before the Internet." According to one report, Edison made it a habit to work nineteen and one-half hours a day until 1902. Then he "cut back" to eighteen hours. He typically slept for five hours between two o'clock and seven o'clock in the morning, leaving only one hour or less for his social life and family. Presumably, he enjoyed a more relaxed schedule on the weekends. ${ }^{2}$

Edison worked hard, and he expected his laboratory experimenters to do likewise. Rarely, however, did he push his men as hard as he did in September and October 1912, when "seven loyal, young, and vigorous employees" worked with the inventor night and day for a span of five weeks to resolve a problem relating to the commercialization of Edison's new disc record. The achievements of the "Insomnia Squad" (as they facetiously called themselves) were immortalized in a group photograph, supposedly taken at two o'clock in the morning, in which the inventor and his assistants are shown taking a brief rest from their work by partaking of a supper of hamburger steak, apple pie, and coffee. ${ }^{3}$

\footnotetext{
${ }^{1}$ Thomas E. Jeffrey is Associate Director and Senior Editor of the Thomas Edison Papers at Rutgers University. ${ }^{2}$ John Swartz, "Living on Internet Time, in Another Age," New York Times, April 4, 2002, available online at Proquest Historical Newspapers; Oliver Simmons, "Edison and His Insomnia Squad," Munsey's Magazine, 58, no. 4 (September 1916), 623-624.

${ }^{3}$ The quotation is from Simmons, "Insomnia Squad," 623. The description and time of the meal appear in the caption to the photograph on page 627. As noted below, it is unlikely that the photograph was actually taken at two o'clock in the morning. Unless otherwise indicated, the term "laboratory" is used in this article to refer to the entire West
} 
Jeffrey

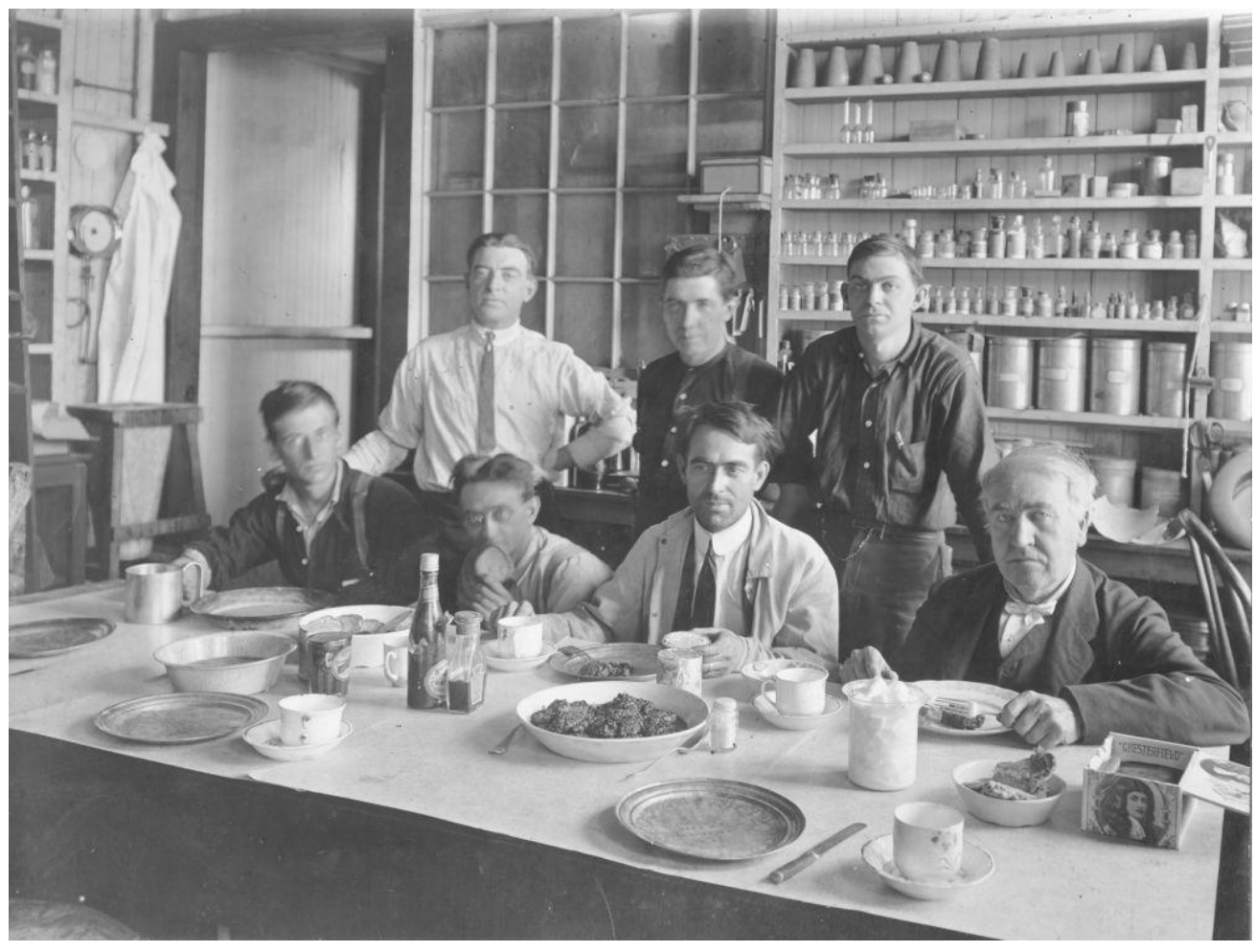

Thomas A. Edison dining at the West Orange laboratory in October 1912, with six of his assistants. Standing from left: Ed McGlynn, Rupert ("Bob") Spahle, and Archibald David ("Archie") Hoffman. Seated from left: John Francis ("Johnny") Lamont, William ("Billy") Fulton, Sherwood Troop ("Sam") Moore, and Edison. Photographic Collection, Thomas Edison National Historical Park, West Orange, N.J.

In the almost one hundred years since that photograph was taken, the phrase "Insomnia Squad" has evolved from an inside joke among a few laboratory staffers into a term familiar even to school children. It is now part of our popular culture and is often used today to characterize Edison's entire laboratory staff going back to the nineteenth century. ${ }^{4}$ However, there is no evidence that the inventor himself ever used that phrase in connection with any members of his staff apart from the experimental team he put together in the fall of 1912. Edison's own nickname

Orange laboratory complex and not merely to the main laboratory (Building 5) in which Edison had his office. ${ }^{4}$ For an example of how the Insomnia Squad has become part of our popular culture, see "Thomas Edison Visits Alpine School," which describes how first-grade student volunteers portraying the Insomnia Squad assist Edison impersonator Patrick Garner with his experiments, Sparta Independent, March 22, 2007, on

http://www.strausnews.com/articles/2007/03/23/sparta independent/news/14.txt, accessed September 1, 2010.

Another example is the Edison Festival of Light, which has been an annual event in Fort Myers, Florida, since 1938. The highlight of the three-week celebration is the two-hour Grand Parade in which the Insomnia Squad are recurrent characters. The 2004 parade featured a roller-blading Insomnia Squad accompanying a float sponsored by Florida Aluminum \& Steel (http://nimue.cyberstreet.com/digiorgiometaldesign/edison, accessed September 1, 2010). 
for the larger group of experimenters was "muckers" - a phrase he probably began using during the 1890 s while working in the iron mines of northwestern New Jersey. ${ }^{5}$

Although the general outline of the Insomnia Squad story has long been known, the documents now available in the microfilm and digital editions of the Thomas A. Edison Papers allow for the construction of a more detailed and richly textured picture of the events of September-October 1912. Together with other sources, they also provide answers to several intriguing questions about the Insomnia Squad. For example, apart from their names, little is known about the seven experimenters who constituted the Insomnia Squad. Edison had a large laboratory staff and an even larger workforce in his factories. Why did he choose these particular individuals to assist him? What motivated Edison to drive his men so hard during these five weeks? Was it nothing more than a desire to solve a technical problem in the shortest amount of time? Or is there a more complicated explanation behind the almost inhuman workload to which Edison subjected his men? The sources agree that seven men assisted Edison with his experiments. Yet there are only six assistants in the photograph. Who, then, was the seventh "Insomniac" and why is he missing from the photograph?

The Insomnia Squad was first mentioned in print by William H. Meadowcroft, the inventor's personal assistant, in a 1913 article entitled "Edison's Pertinacity." As an example of the "fierce vigor with which Edison works when he is seeking to complete one of his inventions" (a characteristic that Edison called "stick-to-it-ive-ness"), Meadowcroft pointed to the events of a year earlier when "Edison and a few of his faithful experimenters (facetiously called 'The Insomnia Squad') stayed steadily at the works for a period of over five weeks - eating, drinking, working and sleeping (occasionally)." According to Meadowcroft, Edison went home only four or five times during that period and then merely to change his clothing. He and his men slept for short periods on benches or tables, resuming their labors as soon as they woke up. The inventor had arranged for a caterer to supply "good substantial meals," and the wives of the experimenters came around at intervals with changes of clothing for their husbands. "This intense application to work left no time for shaving, with the result that all hands might well have been taken for a gang of traditional pirates from their unkempt appearance." Among the illustrations accompanying the article was the group photograph from 1912, with the caption "The Insomnia Squad." However, Meadowcroft did not identify the six experimenters who were posing with Edison. ${ }^{6}$

\footnotetext{
${ }^{5}$ In mining terminology, muckers were the workmen responsible for moving the broken ore into cars so that it could be brought up to the surface. Edison's own use of the term may also be related to the "muck" that was used to bind the briquettes in his ore processing plant. In 1902 a group of experimenters formed a fraternal organization known as the Muckers of the Edison Laboratory. Their minute book can be found in Special Collections Series, Thomas E. Jeffrey et al., Thomas A. Edison Papers: A Selective Microfilm Edition, Part IV (1899-1910) (Bethesda, Md.: University Publications of America, 1999) (hereafter: TAEM IV). Since the publication of Andre Millard's Edison and the Business of Innovation (Baltimore: Johns Hopkins University Press, 1990), it has become fashionable to characterize Edison's Menlo Park and early West Orange laboratory staff as "Muckers," although they never used that name themselves.

${ }^{6}$ William H. Meadowcroft, "Edison's Pertinacity," The Candlestick Magazine (October 1913), Cat. 44,451, Scrapbook Series, Thomas E. Jeffrey, et al., Thomas A. Edison Papers: A Selective Microfilm Edition, Part V(1911-
} 
A year later, Edison himself commented on the events of September and October 1912 in an interview with journalist Edward Marshall in the New York Times. Although the article was written to commemorate the upcoming thirty-fifth anniversary of the invention of the electric light, Edison took advantage of the occasion to expound upon one of his favorite topics-his disdain for oversleeping and overeating. "I never yet have come across the case of a man who had been hurt by want of sleep," he told Marshall. To illustrate his point, he related an occasion "not so very long ago" when "we had a good deal of trouble here in the factory while we were trying to perfect the disk record for our phonographs, and it was plain enough to me that one reason for it was that our work was too much interrupted by the daily routine of our lives."

Edison decided the problem would not be solved until he and his assistants gave it their undivided attention. "Eight of us then started upon the work with very definite intentions of wasting just as little time as possible. For five weeks we put in from 145 to 150 hours a week each at the job. One hundred and fifty hours a week means more than twenty-one hours a day. . . . We became known in the factory as the 'insomnia squad' and we all were proud of the appellation." Marshall asked whether the team had "suffered any ill effects" from their protracted labors. "Ill effects?" Edison chuckled. "No. We all gained weight." The journalist then inquired "what the double quartet of practically sleepless ate during the period of its intense endeavorthe period during which all its members gained weight." "We had plain, workman's food," the inventor answered. “. . . Our diet was not scientific. It was fuel for our physical engines. As I remember it, it consisted principally of potatoes, onions, fried ham, pork and beans and pie. When we felt exhilarated because things were going nicely we sent out for a steak."

Although the article was illustrated with portraits of Edison and Charles P. Steinmetz of General Electric, it did not include the group photograph that had appeared in Meadowcroft's essay a year earlier. Edison did not go into the details of the project that had kept the Insomnia Squad awake for five straight weeks, nor did he mention the names of the seven experimenters who had assisted him. One former employee, who was not a member of the Insomnia Squad, remembered that "the chief resentment of men working in the laboratory was the lack of public recognition which seemed to be their lot. They might have become reconciled to meager salaries had they been accorded due credit for important processes which, from time to time, they perfected." It is not known whether any members of the Insomnia Squad shared that resentment. ${ }^{8}$

Whereas Edison and Meadowcroft had used the Insomnia Squad as an example to illustrate other points, the group was the centerpiece of a six-page article by Oliver Simmons in the September

1919) (Bethesda, Md.: LexisNexis, 2007) (hereafter: TAEM V), 286:568. A draft of this article in Meadowcroft's handwriting can be found in the William H. Meadowcroft Papers, Special Collections Series, TAEM IV, 226:765. Edison is reported to have said that "Genius is hard work, stick-to-it-ive-ness and common sense." See "Edison Defines Genius," Cleveland Plain Dealer, November 20, 1915, Cat. 44,453, Scrapbook Series, TAEM V, $287: 593$. ${ }^{7}$ Edward Marshall, "The Future Man Will Spend Less Time in Bed," New York Times, October 11, 1914.

${ }^{8}$ Richard G. Berger, "With Edison's Insomnia Squad," Modern Mechanix (April 1937), 52, on http://blog.modernmechanix.com/2006/04/27/edisons-insomnia-squad, accessed September 1, 2010. 
1916 issue of Munsey's Magazine entitled "Edison and His Insomnia Squad." Simmons was familiar with Edison's New York Times interview, and he paraphrased several passages for his own piece. His article was also based partly on an interview with Edison's chief engineer, Miller Reese Hutchison. According to Hutchison, the Insomnia Squad was never kept awake merely for the sake of seeing how long the men could hold out. "Mr. Edison knew that the best results in experimenting were accompanied by practically incessant work. ... The man who wants to know how something new will work has got to make a stab at it. The Insomnia Squad went without sleep so that it could keep on stabbing." 9

Two illustrations accompanied the article. One was a half-page photograph of Edison taking a nap on one of the tables in the West Orange laboratory in 1911, during his efforts to develop a suitable reproducer for his disc phonograph. The other was a full-page reproduction of the 1912 photograph of the Insomnia Squad with the caption: "Mr. Edison and His Assistants of the SoCalled Insomnia Squad Taking a Supper of Hamburger Steak, Apple Pie, and Coffee, at Two O'Clock in the Morning, During a Brief Rest from the Night-and-Day Work They Do When Perfecting an Invention." Simmons did not identify any of the "assistants" in the photograph, even though most of them were still working for Edison at the time he talked with Hutchison. Nor did he provide detailed information about their project, stating only that they were "trying to commercialize the diamond-disk record. ... Edison's invention of the disk was perfect, but he had yet to standardize the production of it on a large scale."10

Among those who read the Munsey's Magazine article during the summer of 1916 was a twentythree-year-old college student named Richard G. Berger. A nephew of Victor L. Berger, a Socialist congressman from Wisconsin whose opposition to World War I would later earn him a twenty-year sentence in a federal penitentiary, Richard had recently graduated from the Massachusetts Institute of Technology with a specialty in chemistry. After reading Simmons's article, he immediately wrote to Edison requesting a job in his laboratory. Perhaps to his surprise, he was offered a two-week trial employment at a salary of fifteen dollars per week. Berger reported to the laboratory "fully expecting to be back home at the end of the two weeks." Instead, he remained there for eight months before being laid off on May 7, 1917, for disobeying Edison's orders about how to conduct a chemical experiment. ${ }^{11}$

Twenty years later, Berger published his recollections in an article in Modern Mechanix entitled "With Edison's Insomnia Squad, by Richard G. Berger, a War Time Member." Despite its title,

\footnotetext{
${ }^{9}$ Simmons, "Insomnia Squad," 626.

${ }^{10}$ Ibid., 625, 627, 623. The 1911 photograph has been republished numerous times. See, for example, Lawrence A. Frost, The Edison Album: A Pictorial Biography of Thomas Alva Edison (Seattle: Superior Publishing Co., 1969; Mattituck, N.Y.: Amereon House, 1984), 126; Neil Baldwin, Edison: Inventing the Century (New York: Hyperion, 1995), 324; and Leonard DeGraaf, Historic Photos of Thomas Edison (Nashville: Turner Publishing, 2008$), 57$. These sources do not give the exact date of the photograph nor mention who took the picture. An entry in the diary of Miller Reese Hutchison indicates that Hutchison himself took the photograph on March 6, 1911. See Miller Reese Hutchison Diary, Special Collections Series (hereafter: MRH Diary), TAEM IV, 226:447.

${ }^{11}$ Berger, "With Edison's Insomnia Squad," 50. For his dismissal, see also Berger to W. H. Meadowcroft, May 18, 19, 1917, Employment (E-17-39), Edison General File Series (hereafter: EGF), TAEM V, 268:726, 727.
} 
Jeffrey

the article focused on Berger's own experience working for Edison and not on the events of September-October 1912. However, it did include the photograph of the Insomnia Squad that had previously appeared in the articles by Meadowcroft and Simmons, and, for the first time, the experimenters were identified by name. Lamont, Fulton, and Moore were named as the assistants sitting at the dinner table next to Edison, while McGlynn, Spahle, and Al Hoffman were mentioned as the men standing behind the inventor. ${ }^{12}$

Berger did not give first names for any of the experimenters besides Hoffman, but more complete versions of their names do appear on the back of the print that is preserved among the historic photographs at the Thomas Edison National Historical Park - the current name of Edison's laboratory complex, which was taken over by the National Park Service during the 1950s. According to the inscription, the experimenters are Johnny Lamont, Billy Fulton, Sam Moore, Ed McGlynn, Bob Sphale, and Archie Hoffman. A date of October 18, 1912, has been inscribed along with the names. ${ }^{13}$

If that date represents the day on which the photograph was taken, then the group dinner took place near the end of the marathon session-four days after the Insomnia Squad had achieved their major technological breakthrough. The experimenters are surprisingly well groomed for having been almost continuously awake for five weeks, and only Moore appears to be in need of a shave. Most likely, the dinner was a celebration meal with a staff photographer on hand to document the event, rather than an impromptu break from the work routine as Simmons had indicated. In that case, it is unlikely that the meal took place at two o'clock in the morning. A more plausible scenario is that the men were allowed the opportunity to go home, clean up, and perhaps even get a good night's sleep before the photograph was taken. ${ }^{14}$

Although their names have appeared in several reprints of the photograph, little has been written about the men who constituted the Insomnia Squad. The most comprehensive study of the West Orange laboratory, Andre Millard's Edison and the Business of Innovation, mentions only one member - Sam Moore, Edison's "right-hand man"—and offers just a one-sentence discussion of

\footnotetext{
${ }^{12}$ Berger, "Insomnia Squad," 51. Fulton, Hoffman, Moore, and Spahle were still working at the West Orange laboratory during the period when Berger was employed. The whereabouts of Lamont and McGlynn are unknown, although Lamont had definitely left Edison's employ by September 1918.

${ }^{13}$ There are two inscriptions, with different dates, on the back of the print in the Photographic Collection of Thomas Edison National Historical Park archives (hereafter: TENHP). An earlier inscription, initialed "N R S" (Norman R. Speiden), bears a date of "1912 - Sept 11" and a notation that the "date [is] from [an] old print sent down from Glenmont by Mrs. Edison." The second inscription, initialed and dated "a s 4/1/66," gives the names of the six experimenters, along with a date of "10/18/12" and a source indicated as "E6571" (a set of more than twenty index cards, most of which are now missing). The date inscribed by the later archivist is a more one plausible for the photograph, if it was taken as a celebration picture after the Insomnia Squad had completed most of their work. Since the sources agree that the work went on for about five weeks, September 11 might have been the date on which they began. The September date appears in the caption to the photograph in Frost's Edison Album; the October date is used in DeGraaf's Historic Edison Photos. Whereas Simmons claimed that the photograph was taken at two o'clock in the morning, DeGraaf states that it depicts the experimenters eating lunch. No evidence has been found to corroborate either statement.

${ }^{14}$ The marathon session could not have gone on much beyond October 18, since Edison departed for Akron on October 20.
} 
his role in the laboratory. ${ }^{15}$ A search of the online database of the Thomas A. Edison Papers reveals no trace of Fulton, Lamont, or McGlynn among the almost 150,000 documents indexed thus far and only two documents in which Spahle is mentioned. On the other hand, there are 440 documents in which Moore appears as author, recipient, or name mention and 410 documents for Hoffman. Clearly, these two individuals were key figures in the workforce at West Orange, and it is with them that any account of the Insomnia Squad should begin. ${ }^{16}$

Like the other members of the Insomnia Squad, thirty-six-year-old Sherwood Troop ("Sam") Moore appears to have had no formal education beyond high school. Born in Illinois, he was working in Dayton, Ohio, as a tool maker by his mid-twenties. Some time after 1900 he moved to New Jersey and got a job in one of Edison's factories. His mechanical ability enabled him to advance quickly through the ranks. As one former laboratory employee remembered, "Edison seldom worked with his own hands. He had a mechanical man who did all the manipulating, while the master did the experimenting in his head." 17 After longtime associate John F. Ott became too ill to continue working as Edison's personal machinist, Sam stepped into his shoes. Of medium height and slender build, with brown eyes and black hair, he was - to use a modern expression-Edison's "go-to guy." He was closely involved with disc record experiments all the way into the mid-1920s, and he participated actively in Edison's military research during World War I and his search for a domestic source of rubber in the late 1920s. Not surprisingly, after Edison decided to assemble a task force in September 1912 to resolve the problems encountered in mass producing his disc records, he chose Sam Moore to lead the team. ${ }^{18}$

Moore was the ideal man to lead the Insomnia Squad not only because of his mechanical ability but also because he had a work ethic that matched Edison's. Indeed, as the inventor's wife Mina Miller Edison somewhat ruefully remarked to her son Charles, "he just seems to rejoice in impressing Papa with his untiring energy." By 1912, that combination of talents had made Moore both the central figure in the disc record project and, in Mina's view, an unwelcome rival for her husband's attention. "He depends upon Moore for all the disc recording or disc commercial purposes," she told Charles. "Moore is the only one that has the thing in hand and father thinks

\footnotetext{
${ }^{15}$ Millard, Edison and the Business of Innovation, 288.

${ }^{16}$ Biographical sketches of Insomnia Squad members and approximately 350 additional experimenters, company managers, and family members can be found Thomas E. Jeffrey, From Phonographs to U-Boats: Edison and His "Insomnia Squad" in Peace and War, 1911-1919 (Bethesda Md: LexisNexis, 2008).

${ }^{17}$ Martin A. Rosanoff, "Edison in his Laboratory," Harpers Magazine, September 1932, quoted in George E. Davidson, Beehives of Invention: Edison and His Laboratories (Washington, D.C.: National Park Service, 1973), 42, on http://www.nps.gov/history/history/online_books/hh/edis/index.htm, accessed September 1, 2010.

${ }^{18}$ Moore worked for Edison until the inventor's death in 1931. By that time his son, Sherwood, Jr., was employed by the Edison company as a tool maker. Moore moved to California sometime before 1951 and died in Las Vegas in December 1968. See Social Security Death Index, on http://www.ancestry.com, accessed September 1, 2010. Other primary sources on ancestry.com that were used for these biographical sketches include the U.S. census returns, 1880-1930, and the registration cards that men of draft age were required to fill out for the Selective Service during World War I. These cards are especially valuable sources, since they provide information about physical characteristics, as well as birth year, birth state, residence, and other data. The Edison Herald, an in-house magazine published from 1917 until early 1921, also contains useful biographical information. A complete set can be found at TENHP.
} 
Jeffrey

every thing he says or does is all right. . . It makes me weep to think . . of Papa down here [at the laboratory] all day and night ... [ [with] no thought for any thing but disc and Moore. Moore is never forgotten." 19

Thirty-year-old Archibald David ("Archie") Hoffman was the youngest member of the Insomnia Squad and the only one who could claim any type of higher education. Born in Germantown, New York, Archie moved with his family to Richmond, Virginia, during the mid-1880s and received his early education at the Springfield Grammar School. Around 1900 he moved back north and worked for a time at the Marine Division of the New York, New Haven \& Hartford Railroad. In 1901, he was hired as a wax molder by David A. Dodd, foreman of the Wax Department of the National Phonograph Co. Like Sam Moore, Archie quickly proved his worth and advanced rapidly through the ranks, becoming crew foreman, assistant foreman, and foreman. After his stint on the Insomnia Squad, he would serve as manager of the Disc Blank Department of the Disc Record Manufacturing Division of Thomas A. Edison, Inc., and later as superintendent of manufacturing for the entire division. ${ }^{20}$

While working for Edison, Archie also took courses by mail at the International Correspondence School (ICS) in Scranton, Pennsylvania. The school had been founded in 1890 to teach miners and other workmen the skills needed to advance into the ranks of management. Edison regarded ICS as a "first class institution" and developed a close relationship with it around the turn of the century when the school began using his cylinder phonograph to teach languages. Archie successfully completed a course in chemical engineering and another in cost accounting. He listed those achievements many years later in his application for membership in the Edison Pioneers. He also noted on his application that he had been a "Member of the Insominia Squad.",21

Thirty-six-year-old Rupert ("Bob") Spahle was the only foreign-born member of the Insomnia Squad. Born in Germany, he immigrated to the United States with his parents in 1880 and began working in one of the Edison factories in August 1903. Like other factory employees who demonstrated initiative and above-average ability, Spahle eventually rose into the ranks of management. By 1918 he had advanced to the position of foreman in the Molding Department of the Disc Record Manufacturing Division. A year later, he became assistant to Superintendent

\footnotetext{
${ }^{19}$ Mina Miller Edison (hereafter: MME) to Charles Edison (hereafter: CE), November [1913?], Edison Family Papers-Edison, Mina to Charles Edison, Charles Edison Fund Collection (hereafter: Edison Family Papers, CEF), Thomas A. Edison Papers Digital Edition (hereafter: TAED), Doc. X018A9GH1. Although the quotation is most likely from 1913, it accurately characterizes the situation in 1912. The images in the digital edition can be retrieved at http://edison.rutgers.edu/singldoc.htm by entering the folder and document IDs appearing in these citations. ${ }^{20}$ The National Phonograph Co., established in 1896, merged with several other Edison companies in February 1911 to become Thomas A. Edison, Inc. Hoffman left Edison's employ in 1925 and moved to Irvington, New Jersey, where he was working in 1942 for the General Tool and Manufacturing Co. His younger brother, Frank Oscar Hoffman, also worked for Edison as a general foreman, probably at the Edison Chemical Works in Silver Lake. ${ }^{21}$ Application of Archie D. Hoffman, Edison Pioneers Collection, TENHP. "Insominia" is the spelling on the application. Edison's assessment of ICS can be found in Thomas A. Edison (hereafter: TAE) to M. L. Arthur, June 18, 1906, LB-074, Letterbook Series (hereafter: Letterbooks), TAEM IV, 197:591. ICS is still in existence, although the Scranton-based organization is now known as the Penn Foster Career School. The Canadian branch is still called ICS (http://www.pennfoster.edu, accessed September 1, 2010).
} 
Archie Hoffman. As in the case of many other employees, Bob's two sons would eventually go to work in the Edison factories. ${ }^{22}$

Bob Spahle was only five feet seven inches tall, but he must have towered over thirty-sevenyear-old William ("Billy") Fulton, who at about five feet was the shortest as well as the oldest member of the Insomnia Squad. Born in New Jersey, he was the son of John Fulton, a buttonhole maker for the Singer Manufacturing Co., and his wife Anna. At the time Edison tapped him to work on the Insomnia Squad, Billy was a foreman in one of his factories. He had previously worked as a coner in one of the numerous hat factories that dotted the Orange Valley at the turn of the century. ${ }^{23}$

It is possible that Fulton was recruited for duty on the Squad because of his familiarity with the turntables and other machinery used in hat factories. As indicated below, a revolving turntable that could be tilted as it spun was a key element in the technological breakthrough that the Insomnia Squad achieved in October 1912. In that regard, it is interesting that another member of the Squad, Ed McGlynn, had also most likely worked in a hat factory before entering Edison's employ. $^{24}$

The sixth member of the Insomnia Squad, thirty-four-year-old John Francis ("Johnny") Lamont, was also an experienced factory worker prior to his association with Edison. The oldest son of a Canadian-born carpenter who had immigrated to the United States in 1870, Johnny worked with his younger brother George as a watch-case maker during the early 1900s before being hired to do "record work" for Edison. Like the other members of the Insomnia Squad, Johnny's experience had been in the factory rather than the laboratory. That was only fitting, however, because the challenge that confronted Edison in 1912 was a problem in factory production. ${ }^{25}$

\footnotetext{
${ }^{22}$ Spahle left Edison's employ sometime after 1920. By 1930 he was working in a printing factory in or near West Orange. His daughter-in-law and two of his grandchildren also worked for Edison. See the application of Marguerite Lawless Spahle, Edison Pioneers Collection, TENHP.

${ }^{23}$ A coner was a workman who tended the machine (a perforated metal cone on a revolving turntable) that matted the fur fibers together to form the hat. He then carried the cone from the turntable to the platform of a pedal-operated "sinker" that lowered the cone into heated water to strengthen the fiber cohesion. Sometime between February and September 1918, Fulton went to work for the Splitdorf Electrical Co. in Newark. By 1920 he had returned to Edison's employ and was working in the record factory. A longtime member of the Edison company's volunteer fire department, he became a professional firefighter in West Orange sometime before 1930.

${ }^{24}$ McGlynn is the only member of the Insomnia Squad who cannot be conclusively identified in the U.S. census returns. He is probably Edward Joseph McGlynn (b. 1877), who was living in Orange in April 1910 with his widowed mother and brother and was working as a finisher in a hat factory.

${ }^{25}$ Lamont left TAE's employ sometime before September 1918 and took a job as a drill lathe worker at the International Arms \& Fuze Co., which had a plant adjoining the Edison Chemical Works in Silver Lake. In 1930 he was working as a hospital orderly and living in Newark with his mother and her second husband. Although his name is spelled LaMonte in the inscription on the back of the photograph at TENHP, the signature on his $1918 \mathrm{draft}$ registration card is "John F. Lamont." His name is also consistently spelled Lamont on the census enumerations from 1900 through 1930. In the census of 1910 he is listed as doing "Record Work" at the "Edison fac."
} 
Jeffrey

Edison had earned his reputation as the "Wizard of Menlo Park" with the invention of the phonograph in 1877. Over the years, he had perfected his machines and records, substituting wax and hard plastic for the original tinfoil, but he had steadfastly adhered to the original cylinder format. The sharp decline in sales of Edison phonographs and recordings after 1907, together with the growing popularity of the disc records sold by the Victor Talking Machine Co. and other competitors, motivated the inventor to develop a disc phonograph of his own. The first experiments began in December 1909, and over the next three years most of the technological challenges had been surmounted. By 1912, Edison had perfected a floating-weight recorder assembly and a diamond-point needle that allowed for high-quality recordings and playback. The problem of constructing disc records durable enough to withstand both the heat of the molding process and the pressure of the needle had also been solved with the invention of Condensite, a plastic composition based partly on the patents of Edison's chief chemist Jonas Walter Aylsworth and partly on those of Leo Baekeland. ${ }^{26}$

By September 1912, Edison was ready to go into mass production. Early that month, he invited Karl K. Kitchen of the New York World to visit the music room on the third floor of the main laboratory to write an exclusive story about his new invention. One of Edison's assistants brought over an armful of disc records, and the inventor entertained the journalist with selections from Wagner and Caruso, along with a violin solo by Albert Spalding and "Moonlight in Jungle Land"- a "ragtime ditty sung by a colored quartet." Kitchen was duly impressed. "Never had I heard such a remarkable record," he wrote in regard to one of the recordings. "There was not the slightest scratching at the beginning, nor were any of the sounds that mar phonograph records audible. There was no metallic lustre to the music. It was just as clear and full as if the orchestra had been in the adjoining room." 27

What Kitchen did not know was that Edison had yet to figure out a method of mass producing recordings that could match the quality of the experimental ones the journalist had heard in the laboratory. As chief engineer Miller Reese Hutchison later recalled, "It was a long step from the first demonstration of a new idea to the production of a finished product. Untold labor was entailed in simplifying parts, substituting common materials for the expensive ones used in the laboratory, and in designing articles in such manner as to permit repair and service schedules by their ultimate constructors." The problem that the Insomnia Squad was trying to surmount was a problem in factory production, and the crew that Edison assembled to deal with the challenge were not formally trained chemists or engineers but skilled workmen intimately familiar through decades of experience with the nuts and bolts of factory operations. ${ }^{28}$

\footnotetext{
${ }^{26}$ Paul Israel, Edison: A Life of Invention (New York: John Wiley \& Sons, 1998), 424-426, 430-432. The fourminute disc records sold by Victor had a playing time twice as long as the cylinders sold by Edison. They were also easier to store, more durable, and less expensive because of lower manufacturing costs for both records and machines. Both companies suffered from the 1907 depression. Sales of Edison phonographs and records fell from $\$ 7,104,628$ in 1907 to $\$ 4,831,131$ in 1908 , while Victor's sales dropped from $\$ 6,015,240$ to $\$ 3,631,285$. However, Victor quickly recovered and had exceeded its pre-depression sales by 1910, whereas the sales of cylinder machines and recordings continued to fall, reaching a low of $\$ 2,217,547$ in 1912 . The introduction of the four-minute Edison Amberol Record in 1908 failed to halt the decline.

${ }^{27}$ Karl K. Kitchen, “'I Have Perfected a Non-Scratching, Non-Metallic Phonograph'_-Thomas A. Edison,” New York World, September 8, 1912, Unbound Clippings Series (hereafter: Clippings), TAEM V, 288:251.

28“Dr. Hutchison Tells of Long Work Hours," New York Times, October 25, 1931. Sam Moore was the only member
} 
Edison had a habit of promoting his inventions before the "bugs" had been ironed out, and his disc record was no exception. By September 1912, the inventor had succeeded in creating a sound recording, duplicated from an electroplated master or "matrix," that could be demonstrated to the admiring press. But he had not yet perfected a machine that could coat the fibrous base of the blank records with Condensite varnish in a manner that would entirely eliminate bubbles and particles of dirt and other foreign matter. These impurities in the physical composition of the blank records resulted in distortions in the sound of the finished recordings. Until that problem was surmounted, Edison could not go into mass production. ${ }^{29}$

Edison himself had been putting in long hours on the disc record project even before he assembled the Insomnia Squad to help him resolve the final problem. A newspaper account of the new time clock installed in the laboratory during the summer of 1912 noted that the inventor had logged in ninety-five hours and forty-nine minutes during the week beginning Wednesday, August 21. A brief article in the New York Times on September 5, 1912, remarked that Edison had slept less than twenty-two hours during the previous six work days. "This spurt of energy," it added, "was inspired by the need of finishing touches on his disk phonograph." Edison informed the Times reporter that his invention was "about perfected" and expressed confidence that "he will be able to put it on the market by Oct. 1 or thereabout." 30

Edison's optimistic predictions about putting the phonograph on the market by early October most likely played a part in his decision to assemble a team of experimenters who could give the problem "something approaching undivided attention." ${ }^{31}$ But the inventor had other concerns more compelling than keeping his promises to the press. One was the upcoming Boston Electrical Show, which was scheduled to begin on September 28 and extend until the last week of October. Among the "novel features" planned for the show was the Edison disc phonograph. According to the Boston Herald, "the new disc phonograph has never before been exhibited to the public, and in order to get it ready for the show, Mr. Edison has worked on it night and day." 32

of the Insomnia Squad on the laboratory payroll. The others were all factory employees, and their marathon session took place at the disc record factory (also known as Building 24) rather than in the main laboratory building. As William H. Meadowcroft pointed out, "a great deal of . . experimental work is done in various parts of our factory buildings, in connection with the particular part of the industry to which the experiments relate." See W. H. Meadowcroft to Arthur P. M. Fleming, July 24, 1916, LB-113, Letterbooks, TAEM V, 277:339.

${ }^{29}$ These production problems are mentioned in U.S. Patent 1,234,451. Edison filed the specifications for this patent on October 26, 1912, at the end of the Insomnia Squad's marathon session. A complete set of Edison's U.S. patents can be found on the Thomas A. Edison Papers website, http://edison.rutgers.edu/patents.htm.

30“"Time Card in Edison's Laboratory," Norwalk (Ohio) Reflector, October 5, 1912, Clippings, TAEM V, 288:264; "Edison Forgets to Sleep: He Works 122 Hours Out of 144 to Perfect Disk Phonograph," New York Times, September 5, 1912.

${ }^{31}$ The quotation is from Edison's 1914 interview with Edward Marshall, “The Future Man Will Spend Less Time in Bed."

32“"Novel Features Are Planned for Coming Electric Show," Boston Herald, September 16, 1912, Clippings, TAEM V, 288:254. 
Jeffrey

In fact, the Edison Phonograph Works had already begun the mass production of disc phonographs by the time the Herald article appeared. The phonograph was ready to be put on the market, but Edison had no records to sell along with them. By the end of October the inventor had $\$ 800,000$ worth of phonographs "tied up in the factory," which, he lamented, "I can't ship without discs." It was economic necessity, more than any other factor, which inspired Edison to shift into high gear. ${ }^{33}$

The date on which Edison assembled his Insomnia Squad cannot be determined with certainty. However, if the group photograph of October 18, 1912, was taken on the last day of the marathon session and if the work went on for five weeks, as Edison told Edward Marshall in 1914, the experimenters would have begun their labors around September 13. A more likely date would be September 11-one of the two dates inscribed on the back of the group photograph. Regardless of the exact date on which their work commenced, it is inconceivable that Edison could have pushed himself and his assistants as hard and as long as he did-or that the inventor could have spent so many nights away from home-if his wife had not been out of town during most of the time the Insomnia Squad was working. ${ }^{34}$

For years, Mina Edison had tolerated her husband's unorthodox work habits. All too often, he would send one of his assistants to Glenmont, their elegant Victorian home about a half-mile away from the laboratory, with an apologetic note informing her that he was caught up in an experiment and asking to have supper sent down to the laboratory. But Mina did have her limits. On occasions when she thought her husband was working too hard or neglecting basic hygiene such as washing his face, she would come over to the laboratory, "kidnap" him, and bring him back to Glenmont. For that reason, as one employee recalled, the inventor was happiest when Mina found herself caught up in her own numerous social activities "so that she had less time to look after him and lavish her kindness on him" and "less time to interfere with his experiments." Even better were those occasions when his wife was out of town. As Mina herself jokingly remarked, "When the cat is away the mice will work." 35

\footnotetext{
${ }^{33}$ TAE to Edward H. Johnson, October 30, 1912, LB-091, Letterbooks, TAEM V, 274:655. A draft of this letter in Edison's hand can be found in Personal (E-12-63), EGF, TAEM V, 252:1047.

${ }^{34}$ Wednesday was the first day of the weekly pay period at Edison's laboratory and factories. That also makes September 11, which fell on a Wednesday in 1912, the most likely date on which the Insomnia Squad was formally constituted. It is quite possible, however, that the group began working on Monday, September 9-the day after Mina Edison left town.

${ }^{35}$ Simmons, "Insomnia Squad," 626; Berger, "With Edison's Insomnia Squad," 137; TAE to George F. Morrison, August 18, 1913, David Heitz Collection, TAED, Doc. X225AN.
} 
New Jersey History 125:2

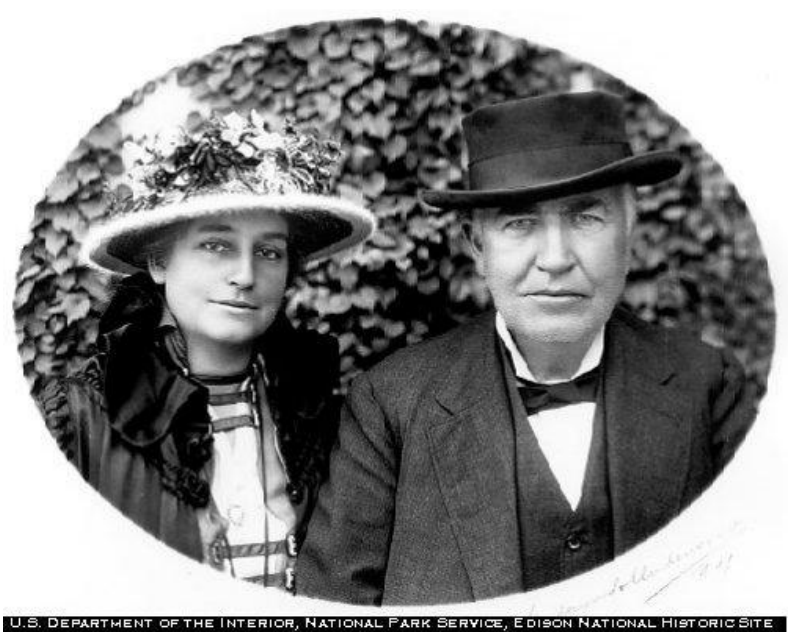

Mina and Thomas Edison, ca. 1908. Mina tolerated her husband's unorthodox work habits, but there were limits to her patience. Photographic Collection, Thomas Edison National Historic Park, West Orange, N.J.

An incident that occurred in February 1912-seven months before Edison assembled his Insomnia Squad-provides telling evidence of the limits of Mina Edison's patience. Edison had spent the evening at the recording studio in New York City, and Mina expected him to come home on the last train. When he did not show up, she telephoned the West Orange laboratory to find out whether he had gone there. Upon learning that he was indeed at the lab, she sent over their chauffeur, George Williams, to pick him up. By now, it was twenty past one in the morning, but George returned empty handed, informing his mistress that the inventor refused to leave. Mina then dressed herself and went over to the laboratory to personally retrieve her errant husband. Edison reluctantly accompanied her home, but, as she later told her son, he "was all broken up so it took until four o'clock for me to get him a little calmed down." "He is all right now," she added, "and loves me just the same." ${ }^{36}$

Mina Edison would never have allowed her husband to remain almost continuously at the laboratory for five straight weeks had she been around to keep an eye on him. It is no coincidence that Edison assembled his Insomnia Squad at the same time that Mina departed with her son Theodore for a ten-day vacation in Monhegan Island, Maine. With daughter Madeleine already at the summer resort and Charles arriving there a few days after his mother and brother, the inventor had more than a week of uninterrupted time to devote to the disc record problem. Perhaps he hoped that most of the work would be done by the time Mina returned to West Orange on September 18. Undoubtedly, her return would have put a damper on Edison's hectic schedule had she not departed for Akron, Ohio, just a few days later to tend to her ailing mother. ${ }^{37}$

\footnotetext{
${ }^{36}$ MME to CE, February 4, 1912, Edison Family Papers, CEF, TAED, Doc. X018A9DQ.

${ }^{37}$ Numerous letters relating to the 1912 vacation on Monhegan Island can be found in Madeleine Edison Sloane Correspondence-1912, David E. E. Sloane Collection, TAED, Folder X400D. These letters indicate that Mina and Theodore arrived at Monhegan on Monday, September 9. They departed for New Jersey on Tuesday, September 17, arriving in West Orange the next day.
} 
Jeffrey

Mina Edison had always maintained a close relationship with Mary Valinda Miller, as is evidenced by the numerous letters published in the microfilm and digital editions of the Thomas A. Edison Papers. By September 1912, eighty-one-year-old Mary Valinda was in very poor health. Nine months earlier, she had suffered a fall from which she had never fully recovered. During the summer of 1912, she came down with a cold that she could not shake. Concerned about his mother's condition, Lewis A. Miller wrote his sister on September 15, suggesting that she come to Ohio to assist him with her care. A week later, Mina departed for Akron, where she would remain for more than a month. ${ }^{38}$

With almost a million dollars of unsold phonographs piling up in his factory, his wife's protracted stay in the Midwest provided Edison with an unexpected opportunity to give the disc record problem "something approaching undivided attention." When he had assembled the Insomnia Squad earlier in September, Edison had underestimated the amount of time that would be required to iron out the bugs in the manufacturing process. By the end of the month, he had come to realize that the "problem [was] more difficult than anticipated." With the "cat" away in Ohio, there was no one to prevent Edison and his "mice" from working night and day until the problem was finally resolved. ${ }^{39}$

The inventor did find time during his labors to dispatch several telegrams to his wife, inquiring about Mary Valinda and expressing optimism about her recovery. "I do not think you need worry about grandma," he reassured her in mid-October. "She has great latent vitality although physically weak." The condition of his mother-in-law provided Edison with yet another strong incentive to resolve the disc record problem as quickly as possible. Mina planned to return to West Orange as soon as her mother showed signs of improvement, and she would certainly apply "tough love" to her workaholic husband once she came back. As Mary Valinda's health deteriorated and Mina repeatedly postponed her plans to come home, an even more ominous thought must have crossed Edison's mind. He might soon have to stop his work completely to travel to Akron and attend a funeral. ${ }^{40}$

\footnotetext{
${ }^{38}$ Lewis A. Miller to MME, September 15, 1912, Charles Edison Fund Collection: Mina Edison Papers, Family Records Series (hereafter: Mina Edison Papers), TAEM V, 284:325. Mina probably did not see this letter until her return to West Orange, although she may have been apprised earlier of its contents. Writing from West Orange on September 20, she told Charles that "I did enjoy being with you at Monhegan, but Grandmother is not well which makes me anxious and question whether I should not have gone to her. . . I shall go out very soon." MME to CE, September 20, 1912, Edison Family Papers, CEF, TAED, Doc. X018A9ER. Mina departed for Akron on September 21 or 22. See TAE to MME, September 23, 1912, Mina Edison Papers, TAEM V, 285:385.

${ }^{39}$ TAE to MME, September 28, 1912, Mina Edison Papers, TAEM V, 285:386. On October 7, the New York Times reported that Edison had had only fifty-six hours of sleep "since he began his final sixteen days of experimentation." See "Edison Discovers He's A Bull Mooser," New York Times, October 7, 1912. That sixteen-day period began around the same day (September 21 or 22) that Mina Edison departed for Akron.

${ }^{40}$ TAE to MME, October 14, 1912, Family (E-12-41), EGF, TAEM V, 252:319. The state of Mary Valinda Miller's health is extensively discussed in nine letters from Mina to Charles Edison written between September 25 and October 15. See Edison Family Papers, CEF, TAED, Folder X018A9. The only communication from Mina to Thomas Edison during this period is a brief telegram from early October expressing "some hope of recovery." See MME to TAE, October 5, 1912, Family (E-12-41), EGF, TAEM V, 252:313. Mina's letters to Charles contain no direct references to Edison's work on disc records, but she did observe that "it makes it easier-a little-to think Papa is glad that I am away." See MME to CE, October 15, 1912, Edison Family Papers, CEF, TAED, Doc. X018A9EZ.
} 
While the Insomnia Squad labored night and day in the factory, Edison also had a business to run. In addition to the disc phonograph, he was working on an improved cylinder record (the Blue Amberol), a dictating machine (the Ediphone), a Kinetophone that would synchronize motion pictures with sound, a Projecting Kinetoscope that could be used to show educational films in schools or entertain the family at home, and an alkaline storage battery that could power light trucks and other vehicles or provide electricity to rural homes that were far away from urban power grids. Nor was Edison's work on disc records limited to the technical side of the business. He was also actively involved in efforts to create a catalog of recording artists and song selections, insisting that every recording in the catalog receive his personal approval. ${ }^{41}$ Edison did not abdicate these other responsibilities during the five weeks he was working with the Insomnia Squad. In addition to communicating with various officials in his company about a wide range of matters unrelated to his disc record experiments, he also responded to numerous incoming letters from business associates. While the disc record project may have been Edison's principal preoccupation in September and October 1912, it was by no means his only concern. ${ }^{42}$

One of Edison's correspondents during this period was Ralph Hamilton Beach, president of the Federal Storage Battery Car Co., who planned to use Edison's battery to power streetcars and commuter railroad trains. On September 19-about a week after the Insomnia Squad began its work-Edison took a break from his routine and strolled over to a nearby abandoned Erie Railroad track to witness the first public demonstration of the Beach car. He spoke briefly to the attending newspapermen about the virtues of his alkaline battery and then went on to talk about the upcoming presidential election, his support for Theodore Roosevelt, and Progressive Party issues like women's suffrage. The interview ended when "Edison's automobile tooted outside the factory, calling him back ... to settle down for another long night's work on his improved phonograph." $" 43$

Another test run of the Beach car took place on September 25, this time over a distance of twenty-five miles on the track of the Long Island Railroad between Penn Station in downtown Manhattan and Long Beach in Long Island. Aboard the train were 150 railroad and electrical engineers who had been invited to make the trip. Early that morning, Beach sent a note to Edison

\footnotetext{
${ }^{41}$ Although Edison was not evaluating songs or recording artists during the five-week period that he was working with the Insomnia Squad, he did communicate with Recording Division head Walter H. Miller at the studio in New York City. See, for example, TAE to W. H. Miller [telephone message], October 7, 1912, Phonograph-General (E12-64), EGF, TAEM V, 253:126.

${ }^{42}$ A search of the Thomas A. Edison Papers online database for the period September 11, 1912-October 18, 1912 reveals more sixty communications between Edison and various officials in his company. On September 16, for example, there are three communications from chief engineer Miller Reese Hutchison (one containing a notation by Edison), one from company president Frank L. Dyer, and three from vice president and general manager Carl H. Wilson. Edison also sent one communication to Hutchison on that day. In addition, there are forty incoming letters for this five-week period that contain marginal notations by Edison.

${ }^{43}$ Will Irwin, "Why Edison Is A Progressive," reprinted in Council Bluffs (Iowa) Nonpareil, September 27, 1912, Clippings, TAEM V, 288:261. The portions of Irwin's article containing Edison's endorsement of Roosevelt and women's suffrage were widely reprinted. These and related clippings establish the date of the interview as September 19. See, for example, Newark Star, September 20, 1912, Clippings, TAEM V, 288:260.
} 


\section{Jeffrey}

inviting him to come along on the outing. "There will be some real people there," he assured the inventor, "and you can be back in New York by six oclock." On less busy occasions, Edison might well have complied with such a request. Instead, he scrawled a response on the bottom of the note: "As I have not been to bed for 30 hours I think sleep is more attractive." 44

By the time the weary inventor wrote that note, he and the Insomnia Squad had been laboring for two weeks, and the end was nowhere in sight. On September 30 Chief Engineer Hutchison commented on Edison's preoccupation with his work, noting in his diary that "TAE hasn't been home since PM of 27th \& hasn't even washed his face since 25th." Applying his own version of tough love in Mina's absence, Hutchison "locked him in [the] Library" and "put him to bed at 2" on the morning of October 1. A few hours later, Edison woke up and finally went home. ${ }^{45}$

Despite his work on the disc record project, Edison continued to find time for other activities. On October 1, for example, he met with Lee DeForest, the inventor of the triode vacuum tube. Five days later, with only fifty-six hours of sleep over the past sixteen days, he chatted "in wideawake tones" with a group of reporters gathered in the library. After answering a number of "questions of political and economical import relating to the presidential campaign," the inventor "scampered back to his workbench and his new phonograph records." On October 9 Edison traveled to New York City with his daughter Madeleine to visit the annual electrical exposition and automobile show at the New Grand Central Palace. He attended a luncheon held in his honor and even took time afterwards to inspect the thousands of electrical appliances on exhibit. Although he undeniably worked long and hard during this period, the traditional account of Edison spending night and day in his factory and coming out only to go home and change his clothes is not an accurate description of reality. ${ }^{46}$

Edison had declined an invitation in September to attend the demonstration of the Beach car, and he had turned down a request in early October to visit the electrical show in Boston. Possibly he might have reacted the same way in regard to the New York City exposition if he had been less hopeful that the problem with the disc records would soon be resolved. By the second week of October, however, his progress reports to Mina had taken on a decidedly more optimistic tone. The situation was "all right here," he informed her the day after he returned from the automobile show. "[I] am still on the problem and things are more promising." Undoubtedly aware that his wife had matters on her mind more important to her than disc records, he added: "How is Grandma?"47

\footnotetext{
44“"Pennsylvania Runs Train by Battery," New York Times, September 26, 1912; R. H. Beach to TAE [undated], Battery, Storage-Federal Storage Battery Car Company (E-12-16), EGF, TAEM V, 251:637. The context of Beach's communication indicates that it was written on September 25, the morning of the test run.

${ }^{45}$ TAE to MME, September 28, 1912, Mina Edison Papers, TAEM V, 285:386; MRH Diary, September 30, October 1, 1912, TAEM IV, 226:550.

${ }^{46}$ MRH Diary, October 1, 1912, TAEM IV, 226:550; "Edison Discovers He's A Bull Mooser," New York Times, October 7, 1912; "'Ware Talking at Electrical Show," New York Times, October 10, 1912; MME to CE, October 11, 1912, Edison Family Papers, CEF, TAED, Doc. X018A9EX.

${ }^{47}$ TAE to MME, October 10, 1912, Family (E-12-41), EGF, TAEM V, 252:316.
} 
The breakthrough for which Edison had been striving finally came on October 14. "Everything [is] progressing well," he telegraphed Mina. "[I] have overcome with certainty the principal troubles, \& can see way pretty clear.” The work of the Insomnia Squad probably ended on Friday, October 18, with the celebration meal commemorated in the group photograph. At eight twenty the following morning, Mary Valinda Miller passed away in Akron. Edison left West Orange on October 20 to attend the funeral and comfort his grieving wife, but not before he had won his race with The Reaper. ${ }^{48}$

The breakthrough that Edison and his assistants achieved in October 1912 can be reconstructed from three patent applications that the inventor filed a few days after his return from Ohio. The most important innovation, embodied in U.S. Patent 1,234,451, was in the design of the metal "transfer plate" that was used to affix the Condensite varnish onto the fibrous base of the blank record. In the new design, a silver plate was surrounded by a detachable supporting ring made of bronze. The plate rotated on a turntable, which was mounted onto a frame that allowed the turntable to be tilted as it spun. As a result of the rotation, the bubbles, dirt particles, and other foreign matter in the varnish being poured onto the plate were thrown to the periphery and collected in the recess of the bronze ring. The ring was then removed from the plate, leaving "a homogeneous veneer free from imperfections" that could be affixed under heat and pressure to the base of the record. Two supplementary patents dealt with the design of the turntable and the feeder used to pour the varnish onto the transfer plate. $^{49}$

${ }^{48}$ TAE to MME, October 14, 1912, MME to TAE, October 19, 1912, Family (E-12-41), EGF, TAEM V, 252:319, 325; "Mrs. Edison's Mother Dies," New York Times, October 21, 1912.

49،Mold or Transfer Plate," U.S. Patent 1,234,451; “Coating Apparatus,” U.S. Patent 1,197,723; "Coating Apparatus," U.S. Patent 1,201,448. The applications were filed on October 26, 1912. An undated note to Sam Moore in one of Edison's pocket notebooks contains three drawings that seem related to the design of the transfer plate. See PN-12-08-16, Notebook Series, TAEM V, 242:375. 

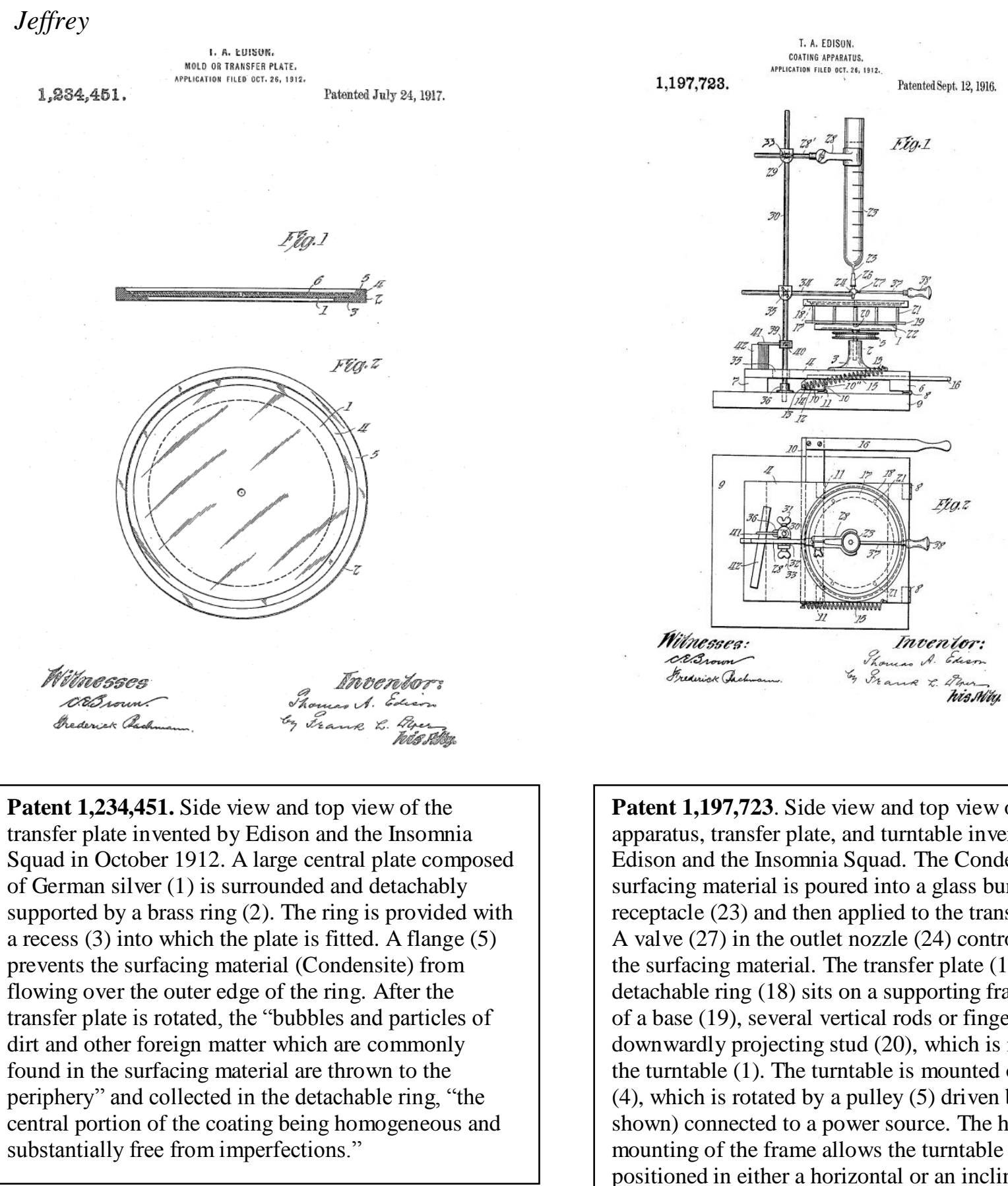

Patent 1,197,723. Side view and top view of the coating apparatus, transfer plate, and turntable invented by Edison and the Insomnia Squad. The Condensite or other surfacing material is poured into a glass burette or similar receptacle (23) and then applied to the transfer plate (17). A valve (27) in the outlet nozzle (24) controls the flow of the surfacing material. The transfer plate (17) with its detachable ring (18) sits on a supporting frame composed of a base (19), several vertical rods or fingers (21), and a downwardly projecting stud (20), which is inserted into the turntable (1). The turntable is mounted on a frame (4), which is rotated by a pulley (5) driven by a belt (not shown) connected to a power source. The hinged mounting of the frame allows the turntable to be positioned in either a horizontal or an inclined position.

Edison stated that his innovation was to be used "in connection with the formation of a veneer for a disk-shaped sound record tablet." He added, however, that "it is not limited to this application, as various changes may be made in the specific construction disclosed without departing from the spirit of the invention." In other words, the Insomnia Squad had not invented 
a new product but rather a new process - a method of lamination with potential industrial applications unrelated to record manufacturing. ${ }^{50}$

The around-the-clock work of the Insomnia Squad came to an end when Edison left for the Midwest on October 20. In announcing his departure, the New York Times reported that "the inventor has just finished a hard campaign in preparation for putting his new disk phonograph on the market." The newspaper speculated that Edison might now be inclined to rest on his laurels and stay for a while "near the scenes of his early life and among the relatives of Mrs. Edison." Most likely, Mina Edison would have preferred that her husband remain for a time with the family in Akron. Instead, he returned to West Orange immediately after the funeral. ${ }^{51}$

Edison was willing to risk his wife's displeasure because there still was work to be done. The "hard campaign" may have ended, but there were smaller problems that had to be overcome before his disc records could be put on the market. On the day of his return to New Jersey, Edison sent an apologetic letter to Charles L. Edgar of the Boston Illuminating Co. explaining why he could not, as he initially had hoped, visit the electric show. His attendance at the funeral, he told Edgar, had "necessitated an absence of several days from the Laboratory at a crucial time in the work on which I have been continuously engaged day and night for the last five or six weeks. I have just returned and find such important matters awaiting me that I cannot see any possibility of getting away even for a day." 52

Edison did not specify the nature of these "important matters." Undoubtedly, he was anxious to protect his new invention with patents, as he and his legal staff immediately began drawing up the formal applications. There were also some technical problems that continued to befuddle him. "I have had great delay in getting our disc machine out," he complained to longtime associate Edward H. Johnson at the end of October, "due as usual to the incompetence of one man." Even after the immediate issues had been resolved and the discs put on the market, quality-control problems with the manufacturing process continued to be a source of concern to Edison for many years to come. The work of the Insomnia Squad had ended, but the Edison Diamond Disc record continued to be a work in progress. ${ }^{53}$

\footnotetext{
50“"Mold or Transfer Plate,” U.S. Patent 1,234,451.

51“"Mrs. Edison's Mother Dies," New York Times, October 21, 1912. Edison grew up in Milan, Ohio, which is about eighty miles away from Akron. According to the Times, Edison stated that "he would be back in West Orange, in all probability, on Tuesday night [October 22]."

${ }^{52}$ TAE to C. L. Edgar, October 23, 1912, LB-091, Letterbooks, TAEM V, 274:653. Although Edison himself was unable to attend the electric show, his disc records were displayed there. They may have been the same experimental recordings that he had shown Kitchen in September. A tabulation of the generally favorable public reaction can be found in "Analysis of Public Opinion of new Edison disc Phonograph, as expressed at Boston Electric Show, Oct. 1912," Phonograph-General (E-12-64), TAEM V, 253:138.

${ }^{53}$ TAE to E. H. Johnson, October 30, 1912, LB-091, Letterbooks, TAEM V, 274:655. Edison did not identify the individual whose "incompetence" was delaying the commercial introduction of his disc, but it may have been Brian F. Philpot, whom the inventor had put in charge of disc manufacturing. Edison dismissed Philpot in May 1913, complaining that he "was no good and simply muddling every thing." See MME to CE, May 7, 1913, Edison Family Papers, CEF, TAED, Doc. X018A9FS. The problems experienced after the discs went on the market included surface noise and a tendency of the Condensite veneer to detach from the core material. Numerous consumer
} 
Thomas Edison continued to work long hours after 1912, but never again would Mina Edison be away from home long enough to allow for a repetition of the Insomnia Squad episode. Indeed, there is some evidence that the rules governing her husband's behavior became stricter after her return from Ohio in October 1912. When the inventor mounted another campaign during the fall of 1913 to resolve the problem of scratches in his disc records, Mina decreed that all work must end by 11:00 p.m. and frequently went down to the laboratory herself to make sure that the edict was enforced. Edison complied with his wife's wishes, but only reluctantly. "No minute this side of eleven P.M. takes our father away from here," she ruefully informed Charles. A year after the Insomnia Squad had completed its work, for Edison it was still "Disc! Disc! Disc!"54

One final question about the Insomnia Squad remains to be answered. In his 1914 New York Times interview, Edison had told Edward Marshall that "eight of us then started upon the work." Yet there are only six men posing with Edison in the group photograph. Only two years had elapsed since the events that Edison was discussing, so it is unlikely that his memory was faulty. Moreover, Oliver Simmons also stated in his 1916 article that there were "seven loyal, young, and vigorous employees" who assisted Edison in his work. So who, then, was the other "Insomniac" and why is he missing from the photograph?

An examination of the three patent applications that Edison filed on October 26, 1912, provides a clue as to his possible identity. Each application begins with a statement that the invention is intended to be used in connection with the "process for forming molded articles" (disc record blanks) developed by Jonas Walter Aylsworth. A chemist by profession, Aylsworth had known Edison for twenty-five years and had worked closely with him to improve his cylinder record and develop a disc. In 1910 he had invented Condensite, the plastic composition that Edison had chosen as the surface coating for his disc record. Since the production problem that confronted the Insomnia Squad involved impurities in the Condensite on the transfer plate, it would be only natural for Edison to summon Aylsworth for help - particularly if, after several weeks of experimentation, it had become obvious (as he told his wife on September 28) that the problem was "more difficult than anticipated." 55

Just as Sam Moore was Edison's "go-to guy" on mechanical issues, Aylsworth was the man to whom the inventor turned when confronting difficult chemical problems. According to a eulogy written after the chemist's untimely death on June 7, 1916, “whenever Mr. Edison found himself confronted by a task involving chemistry in a high degree and requiring the attention of a

complaints about the quality of Edison's disc records can be found in the "Phonograph" folders of the EGF.

Experiments conducted by Edison and his assistants to resolve these problems can be found in the Notebook Series, TAEM V, reels 228-241.

${ }^{54} \mathrm{MME}$ to CE, October 30, 1913, Edison Family Papers, CEF, TAED, Doc. X018A9GH. It should be noted that Edison was recovering at this time from a gall-bladder problem that had sidelined him for most of September. It is unclear whether the eleven o' clock rule remained in force after his recovery.

${ }^{55}$ With the exception of Hoffman, none of the Insomnia Squad had formal training in chemistry. Although he was no longer on Edison's payroll, Aylsworth had his own laboratory in the back of his house on Midland Avenue in East Orange, only a mile away from Edison's laboratory. A brief biographical sketch of Aylsworth, along with a technical discussion of his contribution to the invention of interpenetrating polymer networks, can be found in L. H. Sperling, “Jonas W. Aylsworth: Leif Erickson of Interpenetrating Polymer Networks," Polymer News 12 (1987), $332-334$. 
directing mind for each one of the twenty-four hours, he was rather sure to send for $\mathrm{Mr}$. Aylsworth, for he, too, could do with comparatively little sleep." That talent, of course, made Aylsworth an ideal candidate for the Insomnia Squad. ${ }^{56}$

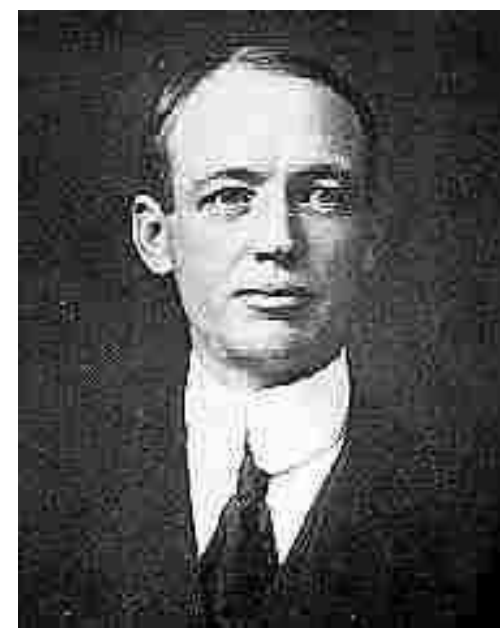

Jonas Walter Aylsworth was the eighth member of the Insomnia Squad. He is not depicted in the group photograph of October 1912. Photographic Collection, Thomas Edison National Historical Park, West Orange, N.J.

The circumstantial evidence points strongly in the direction of Aylsworth as the eighth member of the Insomnia Squad. But is there any hard evidence to support that hypothesis? The "smoking gun," if there is one, should lie somewhere in the documents recently published in Thomas A. Edison Papers: A Selective Microfilm Edition, Part V(1911-1919). A search of the online database for the period during which the Insomnia Squad was working produces two documents in which Aylsworth appears as author, recipient, or name mention. One is irrelevant to the work of the Insomnia Squad. The other is a memorandum written by Edison on September 25, 1912-two weeks into the marathon session. The memo contains the following instructions to an unnamed assistant: "Telephone J. W. Aylsworth Come over to disc building Want to see him." A notation at the bottom of the memo, probably written by the assistant, indicates that the phone call was placed at eight twenty-three in the morning. ${ }^{57}$

The telephone message establishes beyond doubt that Aylsworth was recruited for duty on the Insomnia Squad on September 25, 1912. Whether he had enlisted for the duration is a question that cannot be conclusively answered. It would not be surprising if he spent at least a few sleepless nights working alongside Edison and the others in the disc record factory. But his absence from the group photograph of October 18 suggests that his involvement most likely ended before the Insomnia Squad had completed its work. If that photograph was, in fact, taken at two o'clock in the morning, as Oliver Simmons claimed, Mr. Aylsworth was probably at home, sleeping comfortably in his bed. ${ }^{58}$

\footnotetext{
${ }^{56}$ [Eulogy to J. W. Aylsworth, undated], Articles (E-16-03), EGF, TAEM V, 265:139.

${ }^{57}$ TAE to Jonas Walter Aylsworth [telephone message], September 15, 1912, Phonograph-General (E-12-64), EGF, TAEM V, 253:119.

${ }^{58}$ Apart from the claim by Simmons, there is no evidence that the photograph was actually taken at two o'clock in the morning. As previously indicated, it is more likely that the Insomnia Squad was celebrating the completion of its
} 
Jeffrey

work at a more conventional dining hour. 